\title{
ANALISIS POTENSI EKONOMI KABUPATEN KARANGASEM DAN BANGLI
}

\author{
Ni Kadek Sri Utami ${ }^{1}$ \\ Nyoman Abundanti ${ }^{2}$
}
${ }^{1,2}$ Fakultas Ekonomi dan Bisnis Universitas Udayana (Unud), Bali, Indonesia E-mail:kadeksrieutami@yahoo.co.id

\begin{abstract}
ABSTRAK
Tujuan penelitian ini adalah untuk mengetahui sektor unggulan serta sektor yang berpotensi untuk dikembangkan di Kabupaten Karangasem dan Bangli. Penelitian ini merupakan penelitian kuantitatif yang berbentuk deskriptif yang dilakukan di Kabupaten Karangasem dan Bangli dengan menggunakan data PDRB Kabupaten tahun 2015-2017. Teknik analisis yang digunakan dalam penelitian ini adalah analisis Overlay dan Tipologi Klassen. Berdasarkan hasil analisis mengenai potensi daerah dengan analisis Overlay dan Tipologi Klassen, sektor ekonomi unggulan di Kabupaten Karangasm terdiri dari sektor konstruksi, transportasi dan pergudangan, serta penyediaan akomodasi dan makan minum, sedangkan di Kabupaten Bangli terdiri dari sektor industri pengolahan,konstruksi, serta perdagangan besar dan eceran; reparasi mobil dan sepeda motor. Sektor yang sama-sama berpotensi untuk dikembangkan di Kabupaten Karangasem dan Bangli merupakan sektor ekonomi yang masuk kategori potensial, berkembang, dan terbelakang.
\end{abstract}

Kata kunci: potensi daerah, overlay, tipologi klassen

\section{ABSTRACT}

The purpose of this study is to find out the leading sectors and sectors that have the potential to be developed in Karangasem and Bangli Regencies. This research is descriptive quantitative research conducted in Karangasem and Bangli Regencies using Regency GRDP data for 2015-2017. The analysis technique used in this study is the Overlay analysis and the Klassen Typology. Based on the analysis of the potential of the area with the Overlay analysis and the Klassen Typology, the leading economic sectors in Karangasm Regency consist of the construction, transportation and warehousing sectors, as well as providing accommodation and drinking meals, while in Bangli Regency consists of the processing, construction and large trade industries and retail; car and motorcycle repair. Sectors that have the same potential to be developed in Karangasem and Bangli Regencies are economic sectors that fall into the category of potential, developing, and underdeveloped.

Keywords: regional potential, overlay, classification typology 


\section{PENDAHULUAN}

Otonomi daerah timbul sebagai tuntutan atas buruknya pelaksanaan program pemerintah yang dilaksanakan secara sentralistik. Di Indonesia wujud dari sistem demokrasi itu berupa penerapan otonomi daerah atau desentralisasi yang pada UU No. 32 Tahun 2004 menjelaskan bahwa kewajiban pemerintah daerah untuk dapat mengendalikan daerahnya dengan tetap mengikuti peraturan dan Undang-undang yang berlaku. Pelaksanaan otonomi daerah di Indonesia berlaku sejak tahun 2001. Menurut Anazodo et al. (2016) adanya desentralisasi atau pemberian otonomi akan memberikan ruang bagi pemerintah daerah untuk dapat mengelola sumber daya alam yang dimiliki. Kebijakan otonomi daerah akan menguntungkan daerah yang memiliki sumber daya potensial, sedangkan bagi daerah yang kurang memiliki sumber potensial kebijakan otonomi daerah merupakan kebijakan yang kurang menguntungkan (Norregaard, 2013).

Pemberian otonomi kepada daerah kabupaten/kota didasarkan atas asas desentralisasi sebagai wujud otonomi yang luas, nyata, dan bertanggung jawab yang menjadikan pemerintah daerah kabupaten/kota memiliki tanggung jawab serta wewenang penuh terhadap kebijakan, perencanaan, pelaksanaan, pengawasan, pengendalian, dan evaluasi bagi daerahnya (Habibi, 2015). Pelaksanaan Otonomi Daerah di Indonesia diatur dalam UU No 32 Tahun 2004 mengenai Pemerintah Daerah dan UU No 33 Tahun 2004 mengenai Perimbangan Keuangan antara Pemerintah Pusat dan Pemerintah Daerah. Dalam perjalanan pelaksanaannya, otonomi daerah telah diatur kembali ke dalam UU No. 9 Tahun 2015 yang merupakan perubahan kedua dari UU No. 23 Tahun 2014 mengenai 
pemerintah daerah. Otonomi daerah merupakan hak, wewenang, dan kewajiban pemerintah daerah untuk mengatur serta mengurus rumah tangganya sendiri sesuai dengan peraturan perundang-undangan.Penyelenggaran otonomi daerah memiliki tujuan untuk meningkatkan pelayanan publik (public service) dan memajukan perekonomian daerah (Mardiasmo, 2004).

Adanya kebijakan otonomi daerah diharapkan mampu mendorong setiap daerah untuk menjadi mandiri utamanya dalam memenuhi kebutuhan masyarakatnya. Pasca berlakunya pelaksanaan otonomi daerah, ketergantungan pemerintah daerah terhadap pemerintah pusat semakin meningkat. Peningkatan ketergantungan pemerintah daerah terhadap pemerintah pusat ditunjukkan dari adanya peningkatan perolehan dana transfer (dana perimbangan) untuk pemerintah daerah sebagai penunjang pelaksanaan otonomi daerah. Disisi lain, semakin meningkatkan perolehan dana transfer yang diterima daerah mengindikasikan bahwa pemerintah daerah belum mampu memaksimalkan potensi daerahnya (Halim, 2016:27).

Potensi daerah merupakan sesuatu yang sebenarnya telah ada, namun belum diidentifikasi, sehingga untuk mendapatkannya diperlukan upaya-upaya tertentu untuk memperolehnya. Oleh karena itu, diperlukannya manajemen pendapatan supaya setiap daerah dapat memahami potensi pendapatan yang dimiliki dan memaksimalkan pendapatan untuk membiayai kegiatan publiknya (Halim dan Iqbal, 2012:27). Potensi daerah jika mampu dikelola dengan baik akan mampu meningkatkan pendapatan daerah. 
Pendapatan daerah merupakan semua hak daerah yang diakui sebagai penambah nilai kekayaan bersih dalam periode anggaran tertentu (UU Nomor 32 Tahun 2004). Sumber-sumber pendapatan daerah terdiri dari pendapatan asli daerah, dana perimbangan, dan lain-lain pendapatan daerah yang sah. Pendapatan asli daerah yang meningkat menunjukkan bahwa proporsi modal untuk menyelenggarakan pembangunan daerah juga meningkat, hal tersebut menandakan bahwa adanya partisipasi dari masyarakat terhadap jalannya pemerintah di daerah. Adanya pembangunan sarana dan prasarana serta infrastruktur oleh pemerintah daerah akan memberikan dampak positif bagi pertumbuhan ekonomi daerah. Tolok ukur dalam pertumbuhan ekonomi daerah adalah perolehan atas Produk Domestik Regional Bruto (PDRB) yang meningkat.

PDRB diartikan sebagai total nilai barang dan jasa yang diproduksi di daerah atau provinsi dalam waktu tertentu (satu tahun). PDRB terbagi menjadi dua yaitu PDRB atas dasar konstan dan PDRB harga berlaku. Perbandingan PDRB antar kabupaten/kota dalam satu kawasan menunjukkan bahwa adanya perbedaan tingkat pertumbuhan ekonomi antardaerah dengan ciri-ciri adanya kesenjangan regional dalam satu kawasan (Puspitawati, 2013).

Kawasan Bali Utara dan Timur merupakan daerah yang perkembangan pembangunan dan pertumbuhan ekonominya masih rendah ini terlihat dari laju pertumbuhan (Produk Domestik Regional Bruto) PDRB dari masing-masing Kabupaten/Kota di Bali dalam waktu 3 tahun terakhir.

Tabel 1 menunjukkan kinerja pertumbuhan perekonomian di Bali dalam waktu 3 tahun terakhir. Secara keseluruhan tahun 2017 laju pertumbuhan ekonomi 
di masing-masing kabupaten/kota di Bali mengalami penurunan. Salah satu faktor yang menyebabkan menurunnya perekonomian Bali tahun 2017 adalah adanya peningkatan akitvitas vulkanis Gunung Agung yang menyebabkan pembatalan kunjungan wisatawan baik lokal maupun mancanegara yang berkunjung ke Bali sebagai imbas dari penutupan operasional Bandara I Gusti Ngurah Rai. Kawasan Bali Timur menjadi kawasan yang paling berdampak akibat erupsi Gunung Agung dari segi perekonomian masyarakat dan sektor pariwisata secara keseluruhan di Bali.

Tabel 1.

Laju Pertumbuhan Produk Domestik Regional Bruto(PDRB) Kabupaten/Kota di Bali Tahun 2015-2017 (persen)

\begin{tabular}{lrrr}
\hline \multirow{2}{*}{ Kabupaten/Kota } & \multicolumn{3}{c}{ Laju pertumbuhan PDRB } \\
\hline Jembrana & $\mathbf{2 0 1 5}$ & $\mathbf{2 0 1 6}$ & $\mathbf{2 0 1 7}$ \\
Tabanan & 6,19 & 5,96 & 5,31 \\
Badung & 6,19 & 6,14 & 5,38 \\
Gianyar & 6,24 & 6,81 & 611 \\
Klungkung & 6,3 & 6,31 & 5,5 \\
Bangli & 6,11 & 6,28 & 5,34 \\
Karangasem & $\mathbf{6 , 1 6}$ & $\mathbf{6 , 2 4}$ & $\mathbf{5 , 3 5}$ \\
Buleleng & $\mathbf{6}$ & $\mathbf{5 , 9 2}$ & $\mathbf{5 , 0 8}$ \\
Denpasar & 6,07 & 6,02 & 5,4 \\
Provinsi Bali & 6,14 & 6,51 & 6,08 \\
Sumber: BPS Bali, 2018 & 6,03 & 6,32 & 5,59 \\
\hline
\end{tabular}

Penelitian ini dilakukan di Kabupaten Karangasem dan Kabupaten Bangli, dimana kedua kabupaten ini memiliki potensi daerah yang unik yaitu adanya potensi pada bidang Galian C. Kabupaten Karangasem merupakan salah satu Kabupaten yang terletak di kawasan Bali Timur dengan luas wilayah sekitar $839,54 \mathrm{Km}^{2}$. Selain itu, Kabupaten Karangasem memiliki objek wisata spritual yaitu Pura Besakih dan merupakan letak gunung tertinggi di Bali yaitu Gunung Agung. Kabupaten Karangasem memiliki tradisi yang unik dan keberadaannya saat ini masih terjaga mulai dari tradisi Megibung, Gebug Ende, Perang Api(ter- 
teran) dan yang paling ekstrem yaitu tradisi Perang Pandan di Desa Tenganan. Laju pertumbuhan PDRB Kabupaten Karangasem mengalami penurunan berturutturut dari tahun 2015-2017 yaitu 6 persen; 5,92 persen; dan 5,08 persen. Sementara itu, Kabupaten Bangli merupakan satu-satunya Kabupaten di Bali yang tidak memiliki wilayah laut dengan luas wilayah 520,81 $\mathrm{Km}^{2}$. Kabupaten Bangli menyimpan potensi pariwisata yang menjanjikan yaitu panorama Gunung Batur dan Danau Batur. Kabupaten Bangli sendiri merupakan kabupaten penghasil bambu terbesar di Bali dan merupakan salah satu kabupaten penghasil kopi arabika terbaik di Indonesia dengan kopi yang dihasilkan berkualitas tinggi. Laju pertumbuhan PDRB Kabupaten Bangli secara berturut-turut dari tahun 2015-2017 yaitu 6,16 persen; 6,24 persen; dan 5,35 persen.

Menurut Andriyani dan Utama (2015) sasaran dari pembangunan ekonomi adalah dengan menciptakan pertumbuhan ekonomi serta hasil pembangunan yang merata. Pertumbuhan ekonomi memperlihatkan adanya peningkatan perolehan Produk Domestik Bruto sedangkan pembangunan ekonomi menunjukkan proses yang memiliki tujuan untuk meningkatkan pendapatan perkapita dengan target jangka waktu yang panjang disertai adanya perubahan dalam struktur ekonomi.

Tabel 2.

Produk Domestik Regional Bruto (PDRB) Kabupaten Karangasem dan Bangli Atas Dasar Harga Konstan 2010 menurut Lapangan Usaha Tahun

\begin{tabular}{lccc}
\multicolumn{4}{c}{$\mathbf{2 0 1 6 - 2 0 1 7}$ (Juta Rupiah) } \\
\hline Kabupaten & $\mathbf{2 0 1 5}$ & $\mathbf{2 0 1 6}$ & $\mathbf{2 0 1 7}$ \\
\hline Karangasem & 8.991 .750 & 9.524 .230 & 10.008 .310 \\
Bangli & 3.686 .100 & 3.916 .100 & 4.125 .460 \\
\hline Sumber BPS Bali, 2018 & \multicolumn{3}{l}{}
\end{tabular}

Berdasarkan Tabel 2 terlihat bahwa perolehan PDRB dari Kabupaten Karangasem dan Bangli mengalami peningkatan walaupun laju pertumbuhannya 
Ni Kadek Sri Utami, Analisis Potensi Ekonomi.....

mengalami penurunan yaitu Kabupaten Karangasem memperoleh PDRB secara berturut-turut dari tahun 2015 sebesar 8.991 .750 rupiah, pada tahun 2016 9.524.230 rupiah atau meningkat sebesar 5,92 persen dan tahun 2017 sebesar 10.008.310 rupiah yang meningkat sebesar 5,08 persen. Sektor pertanian merupakan sektor utama pendukung perekonomian Kabupaten Karangasem dengan total kontribusinya terhadap PDRB Kabuptaen Karangasem sebesar 25,11 persen, yang diikuti oleh sektor transportasi dan pergudangan sebesar 16,19 persen. Sementara itu, perolehan PRDB Kabupaten Bangli tahun 2015 mencapai 3.686.100 rupiah, tahun 2016 sebesar 3.916.100 rupiah yang meningkat sebesar 6,24 persen, dan tahun 2017 meningkat menjadi 4.125.460 rupiah yang peningkatannya sebesar 5,35 persen. Sektor pertanian merupakan sektor utama pendukung perekonomian Kabupaten Bangli dengan total kontribusinya terhadap PDRB Kabuptaen Bangli sebesar 25,41 persen.

Menurut Arsyad (2015:374) untuk dapat merancang serta membangun perekonomian suatu daerah, partisipasi dari masyarakat serta pemerintah sangat diperlukan guna menggali potensi sumber daya untuk dimanfaatkan sehingga dapat meningkatkan perekonomian suatu daerah. Pembangunan ekonomi suatu daerah dapat dilakukan dengan meningkatkan daya saing disertai dengan upaya dalam menciptakan keseimbangan antar wilayah sesuai dengan potensi yang dimiliki daerah masing-masing (Diana dkk., 2017).

Penelitian yang dilakukan oleh (Huggis, 2013) menganalisis daya saing suatu daerah menyatakan bahwa model daya saing daerah biasanya didukung oleh sumber daya manusia serta pengetahuan yang dianggap menjadi pendorong utama 
perbedaan pertumbuhan. (Spolaore dan Wacziarg, 2013) pembangunan ekonomi suatu negara tergantung dari tingkat pertumbuhan ekonomi dan faktor geografis negara tersebut. Sementara itu, (Osakede et al., 2016) menyatakan bahwa pembangunan suatu daerah sangat bergantung pada ketersediaan dana serta manajemen yang efisien supaya nantinya pelaksanaan pembangunan menjadi tepat waktu dan efisien.

Kebijakan pembangunan pada dasarnya merupakan keputusan serta intervensi pemerintah pusat maupun daerah guna mendorong pembangunan daerah secara keseluruhan (Hidayat dan Darwin, 2017). Dengan adanya otonomi daerah, kewenangan penuh dalam membangun wilayah diserahkan ke masingmasing pemerintah daerah. Upaya pemerintah daerah dalam meningkatkan pertumbuhan ekonomi dan pemerataan pembangunan dilakukan dengan pembagian wilayah dalam satu kawasan, dimana kawasan ini dijadikan pusat pertumbuhan ekonomi bagi daerahnya sendiri dan daerah sekitarnya. Guna meningkatkan pertumbuhan ekonomi suatu negara kerjasama lintas batas perlu ditingkatkan, hal ini berkaitan dengan area lintas batas yang memiliki potensi signifikan untuk transfer pengetahuan antar organisasi dari kedua perbatasan dalam mengelola potensi daerah (Şlusarciuc, 2015).

Pertumbuhan ekonomi suatu daerah dilihat dari perkembangan PDRB daerah tersebut, dimana pembangunan yang mengacu pada sektor unggulan daerah sangat diperlukan, sehingga akan berdampak pada percepatan pertumbuhan ekonomi juga akan berpengaruh terhadap perubahan mendasar dalam struktur perekonomian wilayah (Sinaga dan Sirojuzilam, 2016). Struktur 
perekonomian yang terjadi pada umumnya bergerak dari sektor primer kemudian menuju sektor sekunder yang selanjutnya ke sektor tersier (Deddy dan Irwansyah, 2013). Pembuatan kebijakan pembangunan suatu daerah harus memperhatikan kondisi riil perekonomian daerah, sehingga nantinya dapat diketahui sektor potensial yang dapat berpengaruh terhadap perekonomian daerah tersebut. Dalam menentukan sektor-sektor ekonomi mana yang memiliki prospek baik untuk dikembangkan dan dapat mendorong sektor-sektor lain untuk berkembang, diperlukan upaya untuk dapat mengidentifikasi potensi-potensi ekonomi yang ada. Upaya yang dapat dilakukan untuk mengetahui potensi ekonomi daerah yaitu dengan mengukur pertumbuhan ekonomi yang berkaitan dengan potensi deerah menggunakan beberapa metode pengukuran yaitu LQ (Location Quotient), Shift Share, (MRP) Model Rasio Pertumbuhan, Overlay, serta Tipologi Klassen (Arsyad, 2015:389).

Beberapa penelitian sebelumnya yang meneliti mengenai analisis potensi ekonomi suatu daerah dengan berbagai metode analisis diantaranya analisis potensial di Malaysia dengan menggunakan analisis shift share menemukan bahwa sektor yang paling efektif adalah sektor industri, manufaktur dan sektor perdagangan serta sektor yang pertumbuhannya pesat adalah sektor konstruksi (Mondal, 2009). Kerimoglu dan Karahasan (2012) meneliti mengenai kesenjangan antar daerah di Spanyol, dimana kinerja ekonomi menunjukkan dampak positif yang signifikan dari bakat aktivitas ekonomi regional. Di sini, bakat diidentifikasi sebagai kelompok individu yang terdidik dan ditempati di sektor-sektor yang dianggap strategis bagi daerah. Putra dan Kartika (2013) dalam penelitiannya 
mengenai analisis sektor potensial dalam menentukan prioritas pembangunan di Kabupaten Badung dengan analisis LQ, MRP, dan Overlay menemukan bahwa sektor dominan di Kabupaten Badung terdiri dari sektor listrik, gas, dan air bersih; sektor bangunan; sektor perdagangan, hotel, dan restoran; serta sektor pengangkutan dan komunikasi.

Dewi dkk. (2014) dalam penelitiannya menggunakan analisis tipologi Klassen dan Indeks Williamson menemukan bahwa struktur pertumbuhan ekonomi kabupaten/kota di Provinsi Bali terbagi dalam tiga pola yaitu : perekonomian daerah yang maju dan tumbuh cepat, daerah berkembang, daerah maju tapi tertekan dan daerah tertinggal. Ratnasari (2014) dalam penelitiannya di Kabupaten Kebumen mengenai analisis sektor ekonomi yang merupakan prioritas untuk dikembangkan guna meningkatkan pertumbuhan ekonomi dengan analisis LQ, Shift Share, MRP, Tipologi Klassen, dan Overlay menemukan bahwa sektor penggalian dan pertambangan adalah sektor maju dan tumbuh dengan pesat atau sektor basis di Kabupaten Kebumen.

Pasaribu (2013) dalam penelitiannya yang menganalisis sektor unggulan terhadap pembentukan PDRB di Kabupaten Simalungun pada tahun 2001-2011 dengan analisis Tipologi Klassen, LQ, dan MRP menemukan bahwa sektor pertanian dan jasa-jasa merupakan sektor maju, sektor basis, serta kompetitif di Kabupaten Simalungun. Ayu dan Wiagustini (2016) dalam penelitiannya menggunakan analisis Tipologi Klassen menemukan bahwa potensi ekonomi yang sama di masing-masing kabupaten/kota di Bali adalah sektor konstruksi, sektor berkembang terdiri dari kesehatan dan kegiatan sosial, sektor potensial 
adalah sektor pertanian, kehutanan, dan perikanan serta sektor terbelakang terdiri dari sektor pengadaan listrik dan gas; sektor pengadaan air, pengolahan limbah sampah dan daur ulang.

Penelitian yang dilakukan oleh Putri dan Suryantini (2018) dengan analisis Tipologi Klassen menemukan bahwa potensi ekonomi daerah Kabupaten Tabanan dan Karangasem pada sektor unggulan adalah sektor penyediaan akomodasi dan makanan minuman sedangkan pada sektor berkembang terdiri dari sektor industri pengolahan, real estate, jasa perusahaan, jasa pendidikan, jasa kesehatan dan kegiatan sosial dan jasa lainnya. Sementara itu, sektor potensial terdiri dari sektor pertanian, kehutanan, dan perikanan, serta sektor konstruksi. Kusumayanti dan Triaryati (2018) dalam penelitiannya di luar wilayah Sarbagita menggunakan analisis Tipologi Klassen menemukan bahwa sektor unggulan di Kabuptaen Bangli terdiri dari sektor industri pengolahan; sektor konstruksi; sektor perdagangan besar dan eceran; reparasi mobil dan sepeda motor, dan sektor penyediaan akomodasi dan makan minum. Sektor unggulan di Kabupaten Jembrana yaitu sektor perdagangan besar dan eceran, reparasi mobil dan sepeda motor; sektor transportasi dan pergudangan; sektor penyediaan akomodasi dan makan minum; sektor informasi dan komunikasi. Sementara itu, sektor unggulan di Kabupaten Klungkung terdiri dari sektor perdagangan besar dan eceran; reparasi mobil dan sepeda motor, sektor penyediaan akomodasi dan makan minum; sektor informasi dan komunikasi; sektor konstruksi; sektor industri pengolahan; sektor administrasi pemerintahan, pertahanan dan jaminan sosial wajib. Kabupaten Buleleng memiliki sektor unggulan yang terdiri dari sektor 
perdagangan besar dan eceran; reparasi mobil dan sepeda motor; sektor penyediaan akomodasi dan makan minum; sektor informasi dan komunikasi; dan sektor jasa pendidikan. Kabupaten Karangasem memiliki sektor unggulan yang terdiri dari sektor transportasi dan pergudangan serta sektor penyediaan akomodasi dan makan minum.

Penelitian yang dilakukan oleh Putra dan Yadnya (2018) dengan menggunakan analisis Tipologi Klassen, LQ, dan Overlay menemukan bahwa sektor perdagangan besar dan eceran; sektor jasa keuangan dan asuransi; serta sektor jasa pendidikan; sektor penyediaan akomodasi dan makan minum, sektor informasi dan komunikasi, sektor industri pengolahan, serta sektor administrasi pemerintah, pertahanan, dan jaminan sosial wajib merupakan sektor unggulan di wilayah sarbagita. Hutajulu et al. (2018) dalam penelitiannya di Kabupaten Pakpak Barat Sumatera Utara dengan analisis Tipologi Klassen, LQ, Least Square Test, menemukan bahwa ekonomi Kabupaten Pakpak Barat terbagi menjadi beberapa kuadran yaitu sektor maju dan berkembang pesat (Kuadran I), maju tetapi tertekan sektor (Kuadran II), sektor potensial (Kuadran III), dan sektor tertinggal (Kuadran IV). Sektor yang diklasifikasikan sebagai sektor maju di Kuadran I dan Kuadran II adalah sektor dasar di Kabupaten Pakpak Bharat dengan $L Q>1$ yaitu sektor pertanian, kehutanan dan perikanan; sektor pengadaan listrik dan gassektor; sektor penyediaan akomodasi dan makan minum; serta pemerintah administrasi, pertahanan dan keamanan sosial wajib. Dapat dikatakan bahwa keempat sektor di atas adalah sektor yang dapat mendorong pertumbuhan 
ekonomi regional sehingga dapat memenuhi kebutuhan wilayah mereka serta mampu mengekspor berbagai komuditas yang dihasilkan.

Perencanaan pembangunan sangat diperlukan guna mengembangkan sektor ekonomi daerah yang dimulai dengan mengidentifikasi sektor unggulan atau potensial ekonomi daerah. Rizani (2017) menyebutkan dua faktor yang harus diperhatikan dalam mengidentifikasi potensi kegiatan ekonomi daerah yaitu sektor ekonomi yang unggul atau memiliki daya saing dalam beberapa periode terakhir dan kemungkinan prospek sektor ekonomi dimasa yang akan dating, serta sektor ekonomi yang potensial untuk dikembangkan dimasa yang akan datang walaupun pada saat ini belum mempunyai tingkat daya saing. Untuk itu, dengan teridentifikasinya potensi ekonomi daerah maka pemerintah daerah dapat menyusun kebijakan pembangunan yang berlandaskan pada upaya meningkatkan pertumbuhan ekonomi daerahnya.

Berdasarkan hasil penelitian sebelumnya yang dilakukan di berbagai daerah menunjukkan bahwa pentingnya untuk menganalisis potensi perekonomian daerah guna membantu memajukan perekonomian dan mampu menyelenggarakan pembangunan daerah.Penelitian ini dilakukan di Kabupaten Karangasem dan Bangli menggunakan analisis Overlay dan Tipologi Klassen, sehingga dengan mengetahui potensi ekonomi yang ada di Kabupaten Karangasem dan Bangli, maka perencanaan pembangunan daerah dalam menghadapi masa yang akan datang dapat lebih terarah serta dapat dijadikan dasar dalam penerapan kebijakan skala prioritas ekonomi guna mempercepat pertumbuhan ekonomi. Rumusan masalah dalam penelitian ini adalah 1) Sektor ekonomi apa saja yang menjadi 
sektor unggulan di Kabupaten Karangasem dan Bangli. 2) Sektor ekonomi apa saja yang berpotensi untuk dikembangkan di Kabupaten Karangasem dan Bangli. Tujuan penelitian ini adalah 1) Untuk mengetahui dan menganalisis sektor ekonomi unggulan di Kabupaten Karangasem dan Bangli. 2) Untuk mengetahui dan menganalisis sektor ekonomi yang berpotensi untuk dikembangkan di Kabupaten Karangasem dan Bangli.

Landasan teori yang digunakan penelitian ini adalah otonomi daerah. Otonomi daerah merupakan hak, wewenang, dan kewajiban daerah otonom untuk mengatur dan mengurus sendiri urusan daerahnya sesuai dengan peraturan yang berlaku. Otonomi daerah diharapkan mampu merangsang pertumbuhan ekonomi daerah (Chibueze, 2011). Menurut Yudistira dan Jember (2015) dengan berlakunya otonomi daerah dapat mempengaruhi laju pertumbuhan ekonomi suatu daerah. Pelaksanaan otonomi daerah mendorong agar pemerintah daerah lebih inisiatif dan inovatif dalam mengelola kekayaan yang dimiliki daerah (Sudewi dan Wirathi, 2013). Dengan diberikannya wewenang kepada pemerintah daerah, diharapkan pemerintah daerah mampu mengatur sendiri masalah kelembagaan dan keuangan daerahnya (Yanusa, 2013). Dalam mengelola keuangan daerah tercermin dari anggaran pemerintah daerah yang dimiliki oleh masing-masing daerah, sehingga nantinya akan digunakan dalam instrumen untuk menciptakan peraturan dalam meningkatkan pembangunan daerah (Lucky, 2013). Selain itu, adanya desentralisasi (pemberian otonomi daerah) diharapkan dapat merangsang pertumbuhan serta perkembangan ekonomi sutau daerah (Chibueze, 2011). Peningkatan pertumbuhan ekonomi daerah dilakukan dengan memanfaatkan 
sumber daya yang dimiliki daerah secara efektif dan efisien. Dengan adanya pelaksanaan otonomi daerah, diharapkan pemerintah kabupaten/kota mampu memaksimalkan potensi daerah yang dimiliki sehingga pendapatan daerah yang nantinya diterima akan meningkat (Uremadu dan Ndulue, 2011).

Pelaksanaan otonomi daerah juga dapat meningkatkan partisipasi lembaga kemasyarakatan dalam membangun ekonomi daerahnya (Ayu dan Wiagustini, 2016), sehingga pemerintah daerah diharapkan menjadi kendaraan untuk penyediaan barang serta jasa yang dibutuhkan sebagai wujud bagian dari pembangunan yang berkelanjutan (Uhunmwuangho dan Aibieyi, 2013). Sebagai tolok ukur keberhasilan pelaksanaan otonomi daerah, pemerintah daerah memiliki tanggung jawab untuk dapat menggali dan mengembangkan potensi daerahnya sebagai sumber penerimaan daerah, maka pelaksanaan pembangunan daerah perlu diarahkan pada sektor-sektor ekonomi daerah yang memberikan multiflier effect terhadap sektor lainnya dan perekonomian secara keseluruhan (Endi dkk., 2015).

Landasan teori kedua adalah PDRB. PDRB (Produk Domestik Regional Bruto) merupakan jumlah nilai dari barang dan jasa akhir yang dihasilkan dari seluruh unit ekonomi pada suatu daerah yang dikenal dengan PDRB menurut lapangan usaha. PDRB terbagi atas PDRB harga berlaku dan PDRB harga konstan Menurut Susanto (2013) untuk dapat menghitung angka yang terdapat dalam Produk Domestik Regional Bruto (PDRB) digunakan tiga pendekatan, yaitu pendekatan produksi, pendapatan, dan pengeluaran. Sumber-sumber utama pendapatan daerah dikelompokkan menjadi tujuh belas sektor lapangan usaha yang terdapat dalam PDRB. 
Landasan teori ketiga adalah potensi daerah. Potensi merupakan sesuatu yang sebenarnya sudah ada namun belum didapat atau diperoleh semaksimal mungkin, sehingga untuk memperolehnya diperlukan upaya-upaya seperti untuk daerah yang memiliki potensi sumber daya alam tambang upaya yang dapat dilakukan dengan eksplorasi dan eksploitasi (Mahmudi, 2010:48). Menurut Deddy dan Irwansyah (2013) sektor ekonomi yang memiliki potensi untuk menjadi sektor penggerak perekonomian adalah sektor yang memiliki memiliki keunggulan kompetitif, daya saing yang tinggi, serta memiliki keunggulan komparatif serta mampu berspesialisasi. Potensi pendapatan antar daerah berbeda, di pengaruhi oleh demografi, ekonomi, sosiologi, budaya, geomorfologi, dan lingkungan yang berbeda, dengan demikian setiap daerah harus memiliki kemampuan yang berbeda dalam menggali potensi ekonominya (Hariyanti \& Utha, 2016). Sementara itu, (Bartle et al., 2011) menyebutkan perolehan pendapatan pemerintah daerah dipengaruhi oleh faktor seperti demografi suatu daerah, perubahan ekonomi serta teknologi.

\section{METODE PENELITIAN}

Penelitian ini dilakukan di Kabupaten Karangasem dan Bangli. Data yang digunakan dalam penelitian ini diperoleh dengan mengakses situs resmi Badan Pusat Statistik (BPS) yaitu www.bps.go.id serta website resmi Kabupaten Karangasem dan Bangli.

Penelitian ini dilakukan untuk menganalisis potensi ekonomi daerah di Kabupaten Karangasem dan Bangli. Adapun obyek yang digunakan dalam penelitian ini adalah sektor-sektor ekonomi yang terdapat dalam PDRB atas dasar 
harga konstan menurut Lapangan Usaha dari Kabupaten Karangasem dan Bangli tahun 2015-2017 yang terdiri dari 17 sektor lapangan usahayaitu 1) Pertanian, Kehutanan, dan Perikanan; 2) Pertambangan dan Penggalian; 3) Industri Pengolahan; 4) Pengadaan Listrik dan Gas; 5) Pengadaan Air, Pengelolaan Sampah dan Daur Ulang; 6) Konstruksi; 7) Perdagangan Besar dan Eceran, Reparasi Mobil dan Sepeda Motor; 8) Transportasi dan Pergudangan; 9) Penyediaan Akomodasi dan Makan Minum; 10) Informasi dan Komunikasi; 11) Jasa Keuangan dan Asuransi; 12) Real estate; 13) Jasa Perusahaan; 14) Administrasi Pemerintahan, Pertahanan dan Jaminan Sosial Wajib; 15) Jasa Pendidikan; 16) Jasa Kesehatan dan Kegiatan Sosial; dan 17) Jasa Lainnya. Teknik analisis yang digunakan adalah kuantitatif deskriptif dengan menggunakan analisis Overlay dan Tipologi Klassen.

\section{HASIL DAN PEMBAHASAN}

Hasil analisis Overlay di Kabupaten Karangasem pada tahun 2015-2017 terdapat lima sektor ekonomi yang memiliki pertumbuhan dominan dan memiliki keunggulan komparatif yaitu sektor pertanian, kehutanan, dan perikanan; transportasi dan pergudangan; jasa keuangan dan asuransi; administrasi pemerintah, pertahanan, dan jaminan sosial wajib; dan jasa lainnya. Terdapat sebelas sektor ekonomi yang memiliki pertumbuhan dominan namun tidak memiliki keunggulan komparatif yaitu sektor ekonomi industri pengolahan; pengadaan listrik dan gas; pengadaan air, pengolahan sampah, limbah dan daur ulang; konstruksi; perdagangan besar dan eceran, reparasi mobil dan sepeda motor; penyediaan akomodasi dan makan minum; informasi dan komunikasi; real 
estate; jasa perusahaan; jasa pendidikan; jasa kesehatan dan kegiatan sosial. Sementara itu, hanya satu sektor yang memiliki pertumbuhan tidak dominan namun memiliki keunggulan komparatif di Kabupaten Karangasem yaitu sektor pertambangan dan penggalian. Penelitian yang sejalan dengan hasil penelitian ini adalah penelitian yang dilakukan oleh Putra dan Yadnya (2018) yang menemukan bahwa sektor administrasi pemerintah, pertahanan, dan jaminan sosial wajib di Kabupaten Tabanan dan Gianyar bahwa merupakan sektor yang memiliki pertumbuhan dominan dan keunggulan komparatif.

Sementara itu, berdasarkan analisis Tipologi Klassen potensi sektor ekonomi di Kabupaten Karangasem terdiri dari Kuadran I (sektor unggulan). Sektor unggulan merupakan sektor yang paling dominan kontribusinya terhadap perekonomian daerah yang kontribusinya terhadap PDRB tinggi dan pertumbuhannya juga tinggi. Aktivitas produksi yang menjadi potensi ekonomi unggulan di Kabupaten Karangasem terdiri dari sektor konstruksi; transportasi dan pergudangan; serta penyediaan akomodasi dan makan minum.

Kuandran II (sektor potensial). Sektor potensial merupakan sektor yang memberikan kontribusi tinggi terhadap perekonomian daerah namun pertumbuhan sektor tersebut lambat serta cenderung menurun yang terdiri dari sektor pertanian, kehutanan, dan perikanan; serta administrasi pemerintahan, pertahanan, dan jaminan sosial wajib. Kuadran III (sektor berkembang). Sektor berkembang ialah sektor yang sedang mengalami peningkatan dari segi pertumbuhannya namun kontribusinya masih rendah. Berdasarkan perhitungan analisis Tipologi Klassen aktivitas produksi yang menjadi potensi ekonomi berkembang di Kabupaten 
Karangasem terdiri dari sektor pengadaan air, pengelolaan sampah, limbah dan daur ulang; perdagangan besar dan eceran; reparasi mobil dan sepeda motor; informasi dan komunikasi; jasa perusahaan; jasa pendidikan; jasa kesehatan dan kegiatan sosial; serta jasa lainnya. Kuadran IV (sektor terbelakang). Sektor Terbelakang merupakan sektor yang menjadi kelemahan daerah yang diindikasikan dengan pertumbuhan lambat serta kontribusinya terhadap PDRB masih rendah. Berdasarkan perhitungan analisis Tipologi Klassen aktivitas produksi yang menjadi potensi ekonomi terbelakang di Kabupaten Karangasem terdiri dari sektor pertambangan dan penggalian; industri pengolahan; penggadaan listrik dan gas; jasa keuangan dan asuransi; serta real estate.

Berdasarkan gabungan hasil analisis Overlay dan Tipologi Klassen di Kabupaten Karangasem sektor yang masuk kategori unggulan terdiri dari sektor konstruksi, sektor transportasi dan pergudangan, serta sektor penyediaan akomodasi dan makan minum, dimana ketiga sektor ini memiliki pertumbuhan dominan dan berada pada kuadran I yang merupakan sektor ekonomi dengan kontribusi dan pertumbuhannya terhadap perekonomian Kabupaten Karangasem. Dalam mengidentifikasi potensi ekonomi suatu daerah, setelah diketahui kategori sektor unggulan daerah tersebut, kategori sektor ekonomi yang berpotensi untuk dikembangkan juga perlu diketahui. Sektor yang berpotensi untuk dikembangkan merupakan sektor yang masuk kategori sektor potensial, berkembang, dan terbelakang. Kategori sektor potensial di Kabupaten Karangasem terdiri dari sektor pertanian, kehutanan, dan perikanan serta sektor administrasi pemerintahan, pertahanan, dan jaminan sosial wajib. Sementara itu, sektor 
ekonomi yang dikategorikan berkembang di Kabupaten Karangasem terdiri dari sektor pengadaan air, pengelolaan sampah, limbah dan daur ulang; perdagangan besar dan eceran; informasi dan komunikasi; jasa perusahaan; jasa pendidikan; jasa kesehatan dan kegiatan sosial; serta jasa lainnya. Sektor ekonomi di Kabupaten Karangasem yang dikategorikan ke dalam sektor terbelakang terdiri dari sektor pertambangan dan penggalian; industri pengolahan; penggadaan listrik dan gas; jasa keuangan dan asuransi; serta real estate.

Hasil analisis Overlay di Kabupaten Bangli pada tahun 2015-2017 terdapat lima sektor ekonomi yang memiliki pertumbuhan dominan dan memiliki keunggulan komparatif yaitu sektor pertanian, kehutanan, dan perikanan; industri pengolahan; perdagangan besar dan eceran, reparasi mobil dan sepeda motor; administrasi pemerintahan, pertahanan dan jaminan sosial wajib; dan jasa lainnya. Terdapat sebelas sektor ekonomi yang memiliki pertumbuhan dominan namun tidak memiliki keunggulan komparatif yaitu sektor ekonomi pengadaan listrik dan gas; pengadaan air, pengelolaan sampah, limbah dan daur ulang; konstruksi; transportasi dan pergudangan; penyediaan akomodasi dan makan minum; informasi dan komunikasi; jasa keuangan dan asuransi; real estate; jasa perusahaan; jasa pendidikan; serta jasa kesehatan dan kegiatan sosial, dan hanya satu sektor ekonomi yang memiliki pertumbuhan tidak dominan namun memiliki keunggulan komparatif di Kabupaten Bangli yaitu sektor ekonomi pertambangan dan penggalian. Hasil penelitian ini sejalan dengan penelitian yang dilakukan oleh Putra dan Kartika (2013) yang menemukan bahwa sektor yang memiliki 
pertumbuhan dominan adalah sektor perdagangan, hotel, dan restauran serta sektor listrik, gas, dan air bersih.

Berdasarkan analisis Tipologi Klassen aktivitas produksi atau potensi sektor ekonomi di Kabupaten Bangli terdiri dari Kuadran I (sektor unggulan). Sektor unggulan merupakan sektor yang paling dominan kontribusinya terhadap perekonomian daerah yang kontribusinya tinggi terhadap PDRB dan pertumbuhannya juga tinggi yaitu sektor industri pengolahan; konstruksi; serta perdagangan besar dan eceran; reparasi mobil dan sepeda motor.

Kuandran II (sektor potensial). Sektor potensial merupakan sektor yang memberikan kontribusi tinggi terhadap perekonomian daerah namun pertumbuhan sektor tersebut lambat serta cenderung menurun yang terdiri dari sektor pertanian, kehutanan, dan perikanan; penyediaan akomodasi dan makan minum; serta administrasi pemerintahan, pertahanan dan jaminan sosial wajib. Kuadran III (sektor berkembang). Sektor berkembang ialah sektor yang sedang mengalami peningkatan dari segi pertumbuhannya namun kontribusinya masih rendah yang terdiri dari sektor informasi dan komunikasi jasa keuangan dan asuransi; jasa perusahaan; jasa pendidikan; jasa kesehatan dan kegiatan sosial; serta jasa lainnya. Kuadran IV (sektor terbelakang). Sektor Terbelakang merupakan sektor yang menjadi kelemahan daerah yang diindikasikan dengan pertumbuhan lambat serta kontribusinya terhadap PDRB masih rendah. Berdasarkan perhitungan analisis Tipologi Klassen aktivitas produksi yang menjadi potensi ekonomi terbelakang di Kabupaten Bangli terdiri dari sektor pertambangan dan penggalian; 
pengadaan listrik dan gas; sektor pengadaan air, pengelolaan sampah, limbah dan daur ulang; transportasi dan pergudangan; serta real estate.

Berdasarkan gabungan analisis Overlay dan Tipologi Klassen di Kabupaten Bangli, maka sektor ekonomi yang masuk kategori unggulan merupakan sektor ekonomi yang memiliki pertumbuhan dominan yang terdiri dari sektor industri pengolahan, sektor konstruksi, serta sektor perdagangan besar dan eceran, reparasi mobil dan sepeda motor. Sementara itu, sektor ekonomi yang berpotensi untuk dikembangkan merupakan sektor ekonomi yang masuk kategori pontesial, berkembang, dan terbelakang. Sektor ekonomi yang dikategorikan potensial terdiri dari sektor pertanian, kehutanan, dan perikanan; penyediaan akomodasi dan makan minum; serta sektor administrasi pemerintahan, pertahanan, dan jaminan sosial wajib. Sektor ekonomi yang dikategorikan berkembang terdiri dari sektor informasi dan komunikasi; jasa keuangan dan asuransi; jasa perusahaan; jasa pendidikan; jasa kesehatan dan kegiatan sosial; serta jasa lainnya. Sektor ekonomi yang dikategorikan terbelakang terdiri dari sektor pertambangan dan penggalian; penggadaan listrik dan gas; penggadaan air, pengelolaan sampah, limbah dan daur ulang; transportasi dan pergudangan; serta real estate.

Berdasarkan hasil pembahasan mengenai potensi ekonomi daerah Kabupaten Karangasem dan Bangli dengan analisis Overlay dan Tipologi Klassen, maka implikasi dari hasil pemetaan potensi ekonomi daerah bagi kebijakan Manajemen Keuangan Sektor Publik antara lain sektor unggulan merupakan kekuatan dan daya saing daerah dalam meningkatkan perekonomian Kabupaten Karangasem dan Bangli, pemerintah daerah tingkat II harus mampu 
menjaga stabilitas sektor unggulan tersebut. Sektor unggulan suatu daerah bila tidak dikelola dengan baik bisa bergeser menjadi sektor potensial yaitu sektor ekonomi yang kontribusinya terhadap PDRB besar namun pertumbuhannya cenderung mengalami penurunan. Sektor potensial merupakan sektor yang memberikan kontribusi yang besar bagi perekonomian daerah namun pertumbuhannya mulai mengalami penurunan. Sektor potensial bila tidak mendapatkan prioritas dalam pengelolaannya, maka bisa bergeser menjadi sektor terbelakang. Beberapa upaya yang dapat dilakukan dalam dalam meningkatkan perolehan pendapatan dari sektor potensial diantaranya dengan intensifikasi pendapatan, kemitraan dengan pihak swasta, serta pembinaan dan pembenahan meningkatkan kapasitas SDM.

Sektor lain yang juga perlu diperhatikan guna meningkatkan perekonomian Kabupaten Karangasem dan Bangli adalah sektor berkembang dan terbelakang. Sektor berkembang di Kabupaten Karangasem dan Bangli merupakan prospek bagi daerah yang memungkinkan adanya peningkatan kontribusi terhadap perolehan PDRB sehingga bisa bergeser menjadi sektor unggulan. Bila sektor berkembang ini tidak dikelola dengan baik akan dapat bergeser turun menjadi sektor terbelakang. Sementara itu, sektor terbelakang merupakan kondisi dari sektor ekonomi yang memiliki kontribusi lemah dan pertumbuhan yang lambat sehingga dikatakan sebagai kelemahan daerah. Salah satu faktor yang dapat mempengaruhi pengembangan sektor terbelakang adalah kondisi geografis daerah tersebut. Walaupun demikian, agar sektor terbelakang ini tetap mampu mengoptimalkan perekonomian daerah, pemerintah daerah harus tetap mampu 
mengelolanya. Dalam mengelola sektor terbelakang pemerintah daerah perlu mendapatan pelatihan dan pendidikan serta pengembangan SDM untuk meningkatkan kualitas SDM sehingga kapasitas dalam mengelola potensi daerah menjadi lebih baik.

\section{SIMPULAN DAN SARAN}

Kategori sektor unggulan di Kabupaten Karangasem adalah sektor konstruksi; transportasi dan pergudangan; serta sektor penyediaan akomodasi dan makan minum. Sektor yang berpotensi untuk dikembangkan di Kabupaten Karangasem merupakan sektor ekonomi yang masuk kategori sektor potensial, berkembang, dan terbelakang. Kategori sektor potensial terdiri dari sektor pertanian, kehutanan, dan perikanan serta sektor administrasi pemerintahan, pertahanan dan jaminan sosial wajib. Kategori sektor berkembang terdiri dari sektor pengadaan air, pengelolaan sampah, limbah dan daur ulang; perdagangan besar dan eceran; reparasi mobil dan sepeda motor; informasi dan komunikasi; jasa perusahaan; jasa pendidikan; jasa kesehatan dan kegiatan sosial; serta jasa lainnya. Kategori sektor terbelakang terdiri dari sektor pertambangan dan penggalian; industri pengolahan; pengadaan listrik dan gas; jasa keuangan dan asuransi; serta real estate. Kategori sektor unggulan di Kabupaten Bangli adalah sektor industri pengolahan; konstruksi; serta sektor perdagangan besar dan eceran; reparasi mobil dan sepeda motor. Sektor yang berpotensi untuk dikembangkan di Kabupaten Bangli merupakan sektor ekonomi yang masuk kategori sektor potensial, berkembang, dan terbelakang. Kategori sektor potensial terdiri dari sektor pertanian, kehutanan, dan perikanan; penyediaan akomodasi dan makan 
minum; serta sektor administrasi pemerintahan, pertahanan, dan jaminan sosial wajib. Kategori sektor berkembang terdiri dari sektor informasi dan komunikasi; jasa keuangan dan asuransi; jasa perusahaan; jasa pendidikan; jasa kesehatan dan kegiatan sosial; serta jasa lainnya. Kategori sektor ekonomi yang termasuk sektor terbelakang terdiri dari sektor pertambangan dan penggalian; pengadaan listrik dan gas; pengadaan air, pengelolaan sampah, limbah dan daur ulang; transportasi dan pergudangan; serta sektor real estate.

Penelitian ini memiliki keterbatasan dalam mengalisis potensi sektor ekonomi daerah dimana hanya menggunakan kategori berdasarkan sektor ekonomi tanpa memasukkan subsektor dari masing-masing komoditi sektor yang terdapat dalam PDRB sehingga tidak dapat diketahui dengan jelas yang menjadi sektor unggulan daerah. Untuk itu disarankan bagi penelitian selanjutnya untuk menganalisis potensi ekonomi daerah dengan menggunakan subsektor dari komoditi masing-masing sektor dalam PDRB.

Teridentifikasinya sektor unggulan di Kabupaten Bangli yang terdiri dari industri pengolahan, konstruksi, serta perdagangan besar dan eceran; reparasi mobil dan sepeda motor. Sektor industri pengolahan dapat dikatakan sebagai akan memacu dan mengangkat pembangunan sektor lainnya seperti pertanian, perdanggan serta sektor jasa, dalam hal ini pemerintah harus mampu berupaya untuk menarik investor baik swasta maupun pemerintahan sehingga mampu dalam mengembangkan sektor pengolahan tersebut. Pengembangan sektor perdagangan besar dan eceran; reparasi mobil dan sepeda motor dapat dilakukan melalui perbaikan sarana dan prasarana yang mendukung sektor tersebut seperti 
mempermudah dalam mengurus Surat Izin Usaha Perdagangan (SIUP) agar lebih meningkatkan investor baik investor lokal maupun luar daerah.

Pengembangan sektor unggulan hendaknya tidak mengabaikan sektor-sektor ekonomi lainnya, seperti sektor administrasi pemerintahan, pertahanan dan jaminan sosial wajib dimana peningkatan pelayanan kepada masyarakat di zaman modern seperti saat ini dapat dilakukan dengan pengoptimalan sistem online.

\section{REFERENSI}

Anazodo, R. O., Igbokwe-ibeto, C. J., dan Nkomah, B. B. (2016). Local Government Financial Autonomy: A Comparative Analysis of Nigeria and Brazil. Arabian Journal of Business and Management Review, 5(10), 38-54. Retrieved from http://www.arabianjbmr.com/pdfs/OM_VOL_5_\%2810\%29/3.pdf

Andriyani, N. Ny. S., dan Suyana Utama, M. (2015). Analisis pusat pertumbuhan di kabupaten karangasem. E-Jurnal Ekonomi Pembangunan Universitas Udayana, 4(4), 220-229.

Retrieved from https://ojs.unud.ac.id/index.php/eep/article/view/11381/0

Arsyad, L. (2015). Ekonomi Pembangunan (5th ed.). Yogyakarta: UPP STIM YKPN.

Ayu Sudewi, N. N., dan Wirathi, I. G. A. . (2013). Pengaruh desentralisasi fiskal dan pertumbuhan ekonomi terhadap kemiskinan propinsi bali. E-Jurnal Ekonomi Pembangunan Universitas Udayana, 2(3), 135-141.

Retrieved from https://ojs.unud.ac.id/index.php/eep/article/view/4434

Bartle, J. R., Kriz, K. A., dan Morozov, B. (2011). Local government revenue structure: Trends and challenges. Journal of Public Budgeting, Accounting and Financial Management, 23(2), 268-287. https://doi.org/10.1108/JPBAFM-23-02-2011-B005

Chibueze C. Ikeji. (2011). Politics of Revenue Allocation in Nigeria: a reVisitation. Sacha Journal of Policy and Strategic Studies, 1(1), 121-136. https://doi.org/10.5901/mjss.2011.v2n3p299

Deddy, M., dan Irwansyah, S. (2013). Analisis Pergeseran Struktur Ekonomi dan Identifikasi Sektor Potensial Wilayah Pengembangan (Studi Kasus di Kabupaten Bekasi, Provinsi Jawa Barat). Jurnal Social Economic of 
Agriculture, 2(1), 7-28.

Retrieved from http://eprints.ums.ac.id/41783/1/NASKAH PUBLIKASI.pdf

Dewi, I. A. I. U., Budhi, M. K. S., dan Sudirman, W. (2014). Analisis Ketimpangan Pembangunan Antara Kabupaten / Kota Di Provinsi Bali. Jurnal Ekonomi Dan Bisnis Universitas Udayana, 68-80.

Retrieved from http://ojs.unud.ac.id/index.php/EEB/article/view/7494

Diana, M., Sulistiowati, D., dan Hadi, S. (2017). Analisis Sektor Ekonomi Unggulan Di Provinsi Maluku Utara. Ilmu Ekonomi, 1(4), 400-415.

Retrieved

from

http://ejournal.umm.ac.id/index.php/jie/article/download/6280/5645

Dinata Sinaga, M. P., dan Sirojuzilam. (2016). Analisis Potensi Ekonomi Wilayah Sumatera Utara.

Retrieved from https://text-id.123dok.com/document/dy4w50qn-analisispotensi-ekonomi-wilayah-provinsi-sumatera-utara.html

Endi, R., Suparta, I. W., dan Husaini, M. (2015). Analisis Sektor Unggulan dan Pengembangan Wilayah di Kota Bandar Lampung 2000-2012. Jurnal Ekonomi Pembangunan Universitas Lampung, 4(1), 107-134.

Retrieved from http://digilib.unila.ac.id/7472/2/ABSTRAK.pdf

Habibi, M. M. (2015). Analisis Pelaksanaan Desentralisasi dalam Otonomi Daerah Kota/Kabupaten. Jurnal Pendidikan Pancasila Dan Kewarganegaraan, 28(2), 525-537. https://doi.org/10.1016/0014-4894(54)90048-X

Halim, A. (2016). Manajemen Keuangan Sektor Publik. Jakarta: Salemba Empat.

Halim, A., dan Iqbal, M. (2012). Pengelolaan Keuangan Daerah. Yogyakarta: STIM YKPN.

Hariyanti, D., dan Utha, M. A. (2016). Analysis of Determinants Sectors Regional Development at 33 Provinces in Indonesia. OIDA International Journal of Sustainable Development, 09(03), 1923-6654.

Retrieved from http://www.oidaijsd.com/Files/Volume09-Issue03.pdf

Hidayat, M., dan Darwin, R. (2017). Analisis Sektor Unggulan Dalam Pengembangan Wilayah Kabupaten Kepulauan Meranti. Media Trend, 12(2), $156-167$.

https://doi.org/10.21107/mediatrend.v12i2.3081

Hutajulu, D. M., Nasir, M., dan Arwansyah. (2018). Analysis of the Leading Sector and the Effect of the Economic Growth: A Case Study in Pakpak Bharat Regency, Indonesia. Studia Universitatis „Vasile Goldis” Arad - 
Economics Series, 28(3), 37-49.

https://doi.org/10.2478/sues-2018-0014

Kerimoglu, E., dan Karahasan, B. C. (2012). Geography of Talent for Understanding. Journal of Urban and Regional Analysis, 4(2), 103-128.

Retrieved from https://www.researchgate.net/publication/254424598_Geography_of_talent_ and_regional_differences_in_Spain

Kusumayanti, N. P. A., dan Triaryati, N. (2018). Analisis Potensi Sumber PAD Kabupaten Di Bali Di Luar Wilayah Sabargita. E-Jurnal Manajemen Universitas Udayana, 7(8), 4267-4296.

Retrieved

from https://ojs.unud.ac.id/index.php/Manajemen/article/view/38880

Lucky, D. (2013). Analysis of The Effect of Regional Financial Performance to Economic Growth and Poverty Through Capital Expenditure. Journal of Economics and Sustainable Development, 4(19), 2222-2855.

Retrieved from https://www.iiste.org/Journals/index.php/JEDS/article/download/9804/9989

Mahmudi. (2010). Manajamen Keuangan Daerah. Jakarta: Erlangga.

Mardiasmo. (2004). Otonomi dan Manajemen Keuangan Daerah (2nd ed.). Yogyakarta: ANDY.

Mondal, W. I. (2009). An Analysis Of The Industrial Development Potential Of Malaysia: Journal of BUsiness and Economics Research, 7(5), 41-46. Retrieved from http://www.cluteinstitute.com/ojs/index.php/JBER/article/view/2289

Norregaard, J. (2013). Taxing Immovable Property Revenue Potential and Implementation Challenges. IMF Working Papers, 13(129), 1. https://doi.org/10.5089/9781484369050.001

Nur Ayu, L. N. F., dan Wiagustini, N. L. P. (2016). Potensi Ekonomi Daerah Provinsi Bali, 5(12), 7528-7554.

Retrieved from https://ojs.unud.ac.id/index.php/Manajemen/issue/view/2212

Osakede, K. O., Ijimakinwa Samuel o, dan Adesanya, T. O. (2016). Local Government Financial Autonomy in Nigeria: An Empirical Analysis. Kuwait Chapter of Arabian Journal of Business and Management Review, 5(11), 2438.

Retrieved from www.arabianjbmr.com

Pasaribu, O. (2013). Analisis penentuan sektor unggulan di kabupaten 
simalungun, $1(1), 245-256$.

Retrieved from http://repository.usu.ac.id/handle/123456789/55615

Puspitawati, L. T. (2013). Analisis Perbandingan Faktor-Faktor Penyebab Ketimpangan Pembangunan Antar Kabupaten/Kota di Kawasan Kedungsapur. E-Jurnal Ekonomi Pembangunan Universitas Negeri Semarang, 2(2), 1-16.

Retrieved from https://journal.unnes.ac.id/sju/index.php/edaj/article/view/1655\%09\%0A\%0 A

Putra, G. B. N. P., dan Kartika, I. N. (2013). Analisis Sektor-Sektor Potensial Dalam Menentukan Prioritas Pembangunan di Kabupaten Badung Tahun 2001-2011. E-Jurnal Ekonomi Pembangunan Universitas Udayana, 2(9), 401-405.

Retrieved from https://media.neliti.com/media/publications/44630-IDanalisis-sektor-sektor-potensial-dalam-menentukan-prioritas-pembangunandi-kabup.pdf

Putra, P. I., dan Yadnya, I. P. (2018). Analisis SEktor Unggulan Perekonomian Di Kabupaten/Kota Denpasar, Badung, Gianyar, dan Tabanan, 7(10), 56575685 .

Retrieved from https://ojs.unud.ac.id/index.php/Manajemen/article/view/40112\%0A\%0A

Putri, P. L.A., dan Suryantini, N. P. S. (2018). Studi Komparatif Potensi Ekonomi dan Tingkat Kemandirian Daerah Kabupaten Tabanan dengan Kabupaten Karangasem. E-Jurnal Manajemen Universitas Udayana, 7(4), 1802-1830.

Retrieved from https://journal.unnes.ac.id/sju/index.php/edaj/article/view/1655\%09\%0A\%0 A

Ratnasari, E. D. (2014). Sectors analysis and determination of GDP forming leading sector in district Kebumen. Jurnal Fokus Bisnis, 13(01), 1-29.

Retrieved from http://scholar.google.co.id/citations?user=SVl5JK8AAAAJdanhl=id

Rizani, A. (2017). Analisis Potensi Ekonomi Di Sektor dan Subsektor Pertanian, Kehutanan, dan Perikanan Kabupaten Jember. E-Jurnal Ekonomi Pembangunan Universitas Tarakan, 15(2), 138-156.

Retrieved from http://ejournal.umm.ac.id/index.php/jep/article/download/5361/5203

Şlusarciuc, M. (2015). The Economic Potential of Crossborder Areas. Opportunities and Threats. Procedia Economics and Finance, 32(15), 801- 
808.

https://doi.org/10.1016/S2212-5671(15)01465-3

Spolaore, E., dan Wacziarg, R. (2013). How Deep Are The Roots Of Economi Development.

Retrieved from https://www.nber.org/papers/w18130

Susanto, D. A. (2013). Analisis Potensi Ekonomi Sub Sektor Industri Pengolahan Kota Tangerang. Nucleic Acids Research, 34(11), e77-e77.

Suyana Utama, M. (2010). Buku Ajar Ekonomi Regional. Denpasar: Fakultas Ekonomi dan Bisnis Universitas Udayana.

Uhunmwuangho, S. O., dan Aibieyi, S. (2013). Problems of revenue generation in local government administration in Nigeria, 2(3), 2227-5452.

Retrieved from https://ojs.unud.ac.id/index.php/Manajemen/article/view/40112\%0A\%0A

Uremadu, S. O., dan Ndulue, J. C. (2011). A review of private sector tax revenue generation at local government level : Evidence from Nigeria, 3(June), 174183.

UU No 32 Tahun 2004. Pemerintah Daerah. Indonesia.

UU No 33 Tahun 2004. Perimbangan Keuangan Antara Pemerintah Pusat dan Daerah. Indonesia.

Yanusa, A. I. (2013). Assessment of Financial Peerfomance of Anka Local Government Council of Kogi State. Internasional Journal of Social Sciences and Humanities Reviews, 4(1), 67-79.

Retrieved from http://www.ijsshr.com/journal/index.php/IJSSHR/article/view/137/121

Yudistira, I. B., dan Jember, I. M. (2015). Pengaruh Desentralisasi Fiskal Dan Korupsi Terhadap Pertumbuhan Ekonomi Di Provinsi Bali. E-Jurnal Ekonomi Pembangunan Universitas Udayana, 4(2), 121-128.

Retrieved from http://www.oidaijsd.com/Files/Volume09-Issue03.pdf 